Niina AAsmÄE (Tartu)

\title{
The observations of Heikki Paasonen concerning word stress in Erzya and Moksha
}

\begin{abstract}
The present paper focuses on H. Paasonen's observations concerning word stress in the dialects of Erzya and Moksha. The material collected by H. Paasonen during his research journeys is a valuable research source on the state of the Erzyan and Mokshan dialects at the turn of the nineteenth and twentieth century. H. Paasonen's ideas concerning word stress in Erzya and Moksha have been pivotal in this area of research now for more than a century. With the historical source as a background, the author evaluates the present-day findings in the subject.
\end{abstract}

\section{Introduction}

In the history of research on the Mordvin languages, Heikki Paasonen's monograph on Mordvin phonetics ("Mordvinische Lautlehre", SUST XXII, Helsingfors, 1903, printed as a dissertation in 1893) stands out as a unique research source. In 1973, Paavo Ravila wrote: "Seit H. Paasonen seine immer noch unersetzliche Untersuchung "Mordvinische Lautlehre" (1893 als Dissertation und 1903 mit Berichtigungen ergänzt als MSFOu XXII) veröffentlichte, hat man über die Akzentuierung im ErzaMordwinischen nichts wesentlich Neues vorbringen können" (Ravila 1973: 169).

It should be emphasized that the questions posited by H. Paasonen in his works on the language prosody and the poetic metre in Mordvin (Paasonen 1893/1903; 1897; 1910) have continually been of interest (for literature on the issue, see e.g. Korhonen 1994).

This paper focuses on the manifestations of stress in Erzyan and Mokshan dialects, as described by H. Paasonen (1893/1903), and on some of the experimental data published during the last two decades mainly by the research group from the University of Tartu working on the prosody of Finno-Ugric languages. ${ }^{1}$ The author identifies the areas where H. Paasonen's observations and the present findings show coherence.

It is not feasible to draw a direct comparison between the sources used by $\mathrm{H}$. Paasonen and the basis of the data available at present since the two sources comprise different language samples evaluated using different research methods. However, an overview of the current experimental data on the background of the statements made by $\mathrm{H}$. Paasonen might be not only acceptable but also informative for the study of prosody in the Uralic languages. To proceed to the analysis, I first provide a survey of the sources used and of the observations made in H. Paasonen's work on the subject of stress in Erzya and Moksha.

1. This research was supported by the Finnish Finno-Ugrian Society and the Estonian Research Agency (grant IUT2-37). 


\section{Sources used by Heikki Paasonen for the description of stress in Erzya and Moksha}

Materials collected by H. Paasonen in several Erzyan and Mokshan localities (see Feoktistov 1990: LVIII for the geography of the observations), as well as data from earlier published literature (see Paasonen 1903: XV-XVI for the sources) constitute the basis of the analyses in H. Paasonen's research. Table I below shows a complete list of the localities mentioned in H. Paasonen's work; the earlier sources of data are marked with a star ${ }^{*}$ ). The table includes references to the present-day names of the localities and dialect group identification (Feoktistov 1990; Feoktistov, Saarinen 2005).

\begin{tabular}{|c|c|}
\hline $\begin{array}{l}\text { List of dialects } \\
\text { (Paasonen 1903: XV-XVI) }\end{array}$ & $\begin{array}{l}\text { Current administrative and dialect group identification } \\
\text { (Feoktistov 1990; Feoktistov, Saarinen 2005) }\end{array}$ \\
\hline \multicolumn{2}{|l|}{ Erzya } \\
\hline $\begin{array}{l}\text { Maresevo (Ardatov, } \\
\text { Simbirsk) }\end{array}$ & Maresevo, maŕeź-vele (Chamzinka, čaunza) - Central \\
\hline $\begin{array}{l}\text { Khlystovka (Ardatov, } \\
\text { Simbirsk) }\end{array}$ & Otradnoye (Chamzinka, čaunza) - Central \\
\hline $\begin{array}{l}\text { Kalyaevo (Temnikov, } \\
\text { Tambov) }\end{array}$ & Kolyaevo, kolaj-vele (Teńgushevo) - Mixed (Shoksha) \\
\hline $\begin{array}{l}\text { *Drakino (Spassk, } \\
\text { Tambov) }\end{array}$ & $\begin{array}{l}\text { Drakino, draka, drakina (Torbeyevo) } \\
\text { - Mixed (Shoksha) }\end{array}$ \\
\hline $\begin{array}{l}\text { *Kazhlytka (Spassk, } \\
\text { Tambov) }\end{array}$ & Kazhlodka, kažlytka (Torbeyevo) - Mixed (Shoksha) \\
\hline *Yegorovka (Samara) & ? Novaya Yegoryevka (Orenburg) - Diaspora \\
\hline \multicolumn{2}{|l|}{ Moksha } \\
\hline $\begin{array}{l}\text { Staroye Pshenevo } \\
\text { (Insar, Penza) }\end{array}$ & Staroye Pshenevo, śiŕa-pšeń (Kovylkino) - Southeastern \\
\hline Selishche (Spassk, Tambov) & Pokrovskiye Selishchi, viĺ-eźəm (Zubova Polyana) - Western \\
\hline Aĺkino (Narovtchat, Penza) & Aĺkino, alka-, alte-vile (Kovylkino) - Transitional \\
\hline *Krasnoslobodsk (Penza) & Krasnoslobodsk, Yeĺniki, Kovylkino regions - Central \\
\hline *Temnikov (Tambov) & Teńgushevo region - Central \\
\hline $\begin{array}{l}\text { *Patra (Krasnoslobodsk, } \\
\text { Penza) }\end{array}$ & Patra, patra-vel̈̈ (Krasnoslobodsk) - Southeastern \\
\hline *Gorodishche (Penza) & $\begin{array}{l}\text { Gorodishche, Sosnoviy Bor region (Penza oblast') - Mixed } \\
\text { (diaspora) }\end{array}$ \\
\hline *Spassk (Tambov) & $\begin{array}{l}\text { Zubova Polyana, Atyuryevo, Temnikov, Torbeyevo regions, } \\
\text { Penza oblast' - Central, Western, Transitional }\end{array}$ \\
\hline
\end{tabular}

Table I. References to the present-day names of the localities and dialect group identification 
According to their geographical position, the localities, with the exception of the Mokshan Gorodishche and the Erzyan Yegorovka, belong nowadays to the administrative units of the Republic of Mordovia. From the point of view of the current taxonomy of dialects (cf. Tsygankin 1979; Yermushkin 1984; Feoktistov 1990; Feoktistov, Saarinen 2005), the materials can be considered representative of all five dialect groups of Moksha and several varieties of the central and mixed (Shoksha) dialects of Erzya.

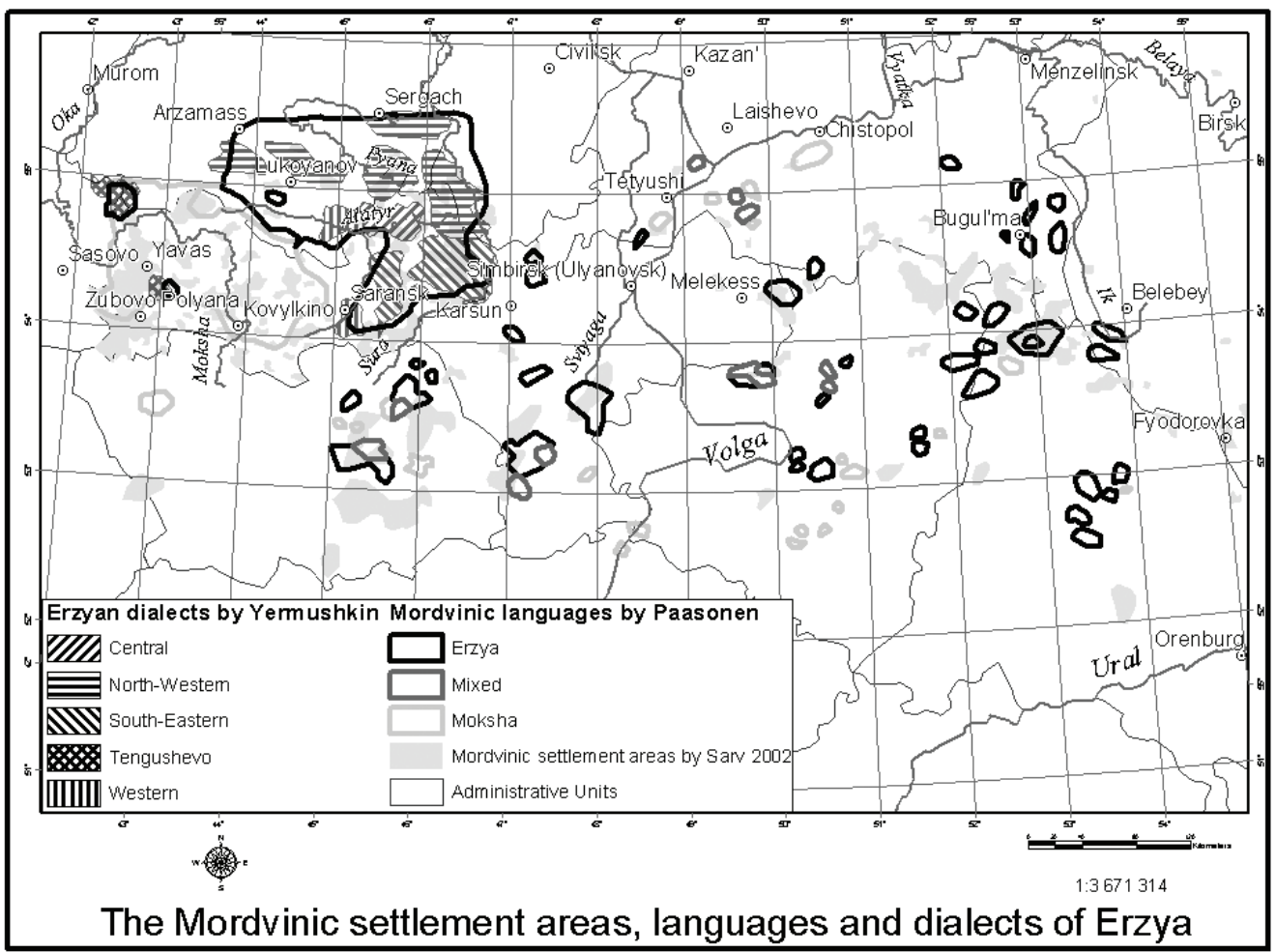

Map I. (see Lehiste et al. 2003: 92; map: Heno Sarv)

\section{Heikki Paasonen's analysis of the features of Mordvin stress}

In "Mordvinische Lautlehre", H. Paasonen compares the manifestations of stress in Erzyan and Mokshan dialects with regard to the perceived acoustic effect of the syllables and the location of the stressed syllable(s) in a word. The well-known statement made by H. Paasonen reads that in Erzya stress is not discernible, while in Moksha it has a clearly expressed effect of prominence (p. 8).

H. Paasonen defines the location of stress in both Erzya and Moksha as free, but he finds that the factors conditioning stress alternation in the two languages differ. In Erzya, the location of stress freely alternates in di- and trisyllabic and even in longer words; in the latter case, though, the term main stress is used. As it seems, $\mathrm{H}$. Paasonen might have perceived a difference, at least, between two degrees of stress 
- main and secondary - in polysyllabic words. However, he has not developed this idea. In the amendments, Paasonen suggests that words in Erzya do not have fixed stress (p. IX).

H. Paasonen adds yet another interesting observation, which he has not made explicit, either. He notes that the assignment of stress in a word constituting a whole intonation phrase may alternate if the phrase reoccurs (p. IX). This might imply that $\mathrm{H}$. Paasonen perceived a dependence of stress assignment on certain characteristics of an utterance.

Concerning stress in Moksha, H. Paasonen states that it may be located on any syllable of the word (p. 8). He provides such examples as a t'akš 'a cock', kafta'st' 'twins' and ato $k \grave{s}$, ka·ftaśt' (pp. 115-116), which also illustrate inter-dialectal variation in the position of stress (the examples are from the sub-dialects of Selishche and Staroye Pshenevo, respectively).

Alongside this, $\mathrm{H}$. Paasonen finds certain regularity about the assignment of Mokshan stress. It ordinarily occurs on the first syllable of the word, but in words that have the high vowels $i$ and $u$ in the first syllable and the low vowel $a$ (or $\ddot{a}$ ) in a subsequent syllable, it tends to shift to the syllable in which low $a$ (or $\ddot{a}$ ) occurs. Thus, the occurrence of low $a$ (or $\ddot{a}$ ) appears to be the factor that causes the shift of stress to a non-initial syllable. H. Paasonen has to admit that dialects vary in this respect and that variation is observable in the speech of informants from the same location as well. For example, the word si i jä 'silver' is pronounced with stress on the first syllable in Staroye Pshenevo but on the second syllable in Selishche: śijä; the words śijä ńn 'of silver' and sijä sa 'in silver' have stress on the second syllable in both varieties (p. 114).

Analysing the variability of the manifestations of stress in the dialects, Paasonen mentions the Erzyan variety of Maresevo, where stress is indistinct, and that of Kazhlytka, where stress is clearly discernible and tends to alternate its location similarly to stress in the Mokshan dialect of Staroye Pshenevo. On this premise, H. Paasonen suggests that the characteristics of original Mordvin stress may have been the same as those observed in the Mokshan variety of Staroye Pshenevo (pp. 118-119).

On the other hand, H. Paasonen draws attention to the fact that there is similarity between Erzya, Southern Khanty, and the majority of Mari dialects, in which the acoustic effect of stress is also indistinct. He finds that this similarity might be of interest for the study of the historical aspect of the proto Finno-Ugric language (p. IX). In the amendments, H. Paasonen writes that he prefers to leave the question of original Mordvin stress open ( $\mathrm{p}$. XIV). 


\section{Current findings on Erzyan and Mokshan stress}

\section{I. Data analysis: Erzya}

Experimental data available at present on the manifestations of stress in the dialects of Erzya and Moksha concern the assignment of stress and the duration of vowels in stressed and unstressed syllables, regarded as a possible correlate of stress.

To draw a parallel between H. Paasonen's and the present-day observations of stress, it is essential to use oral speech materials as the source of experimental data. It is highly probable that $\mathrm{H}$. Paasonen evaluated the characteristics of stress in the informants' oral speech rather than in reading - the majority of Paasonen's informants may have been illiterate. Our preliminary observations of the assignment of stress in Erzya also suggest that variability in the positions of stress in spontaneous oral speech might be higher than in reading, or controlled speech, which is generally less expressive.

In the present analyses, data based on the recordings of oral speech (Erzya) will constitute the main part of the material, while data consisting of controlled speech (Erzya and Moksha) will serve as supporting data. In order to obtain an answer to the question of how free alternating Erzyan stress might be, we conducted an experiment in which the assignment of stress was analysed in one-word utterances of 33 speakers of Erzya. The utterances were recurrent responses to the interviewer's questions, which yielded sets of target words consisting of 2 to 4 syllables.

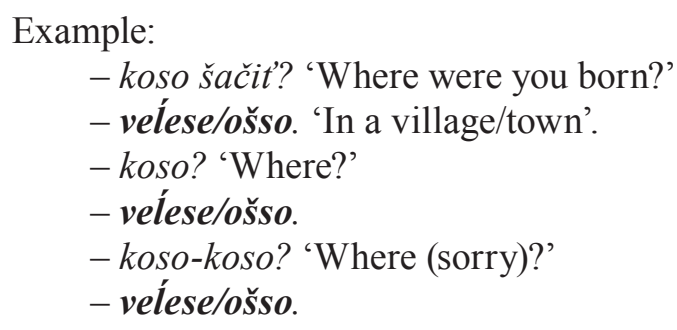

As expected, the position of stress in the target words alternated. In 57\% of the material (number of words: 510), stress was assigned on the word-initial syllable, while in $30 \%$ of the material (number of words: 264), stress occurred on a subsequent syllable. In a part of the utterances, the location of stress in disyllabic and even in longer words was difficult to identify. Such cases amounted to $13-14 \%$ of the total number of words (121); in these cases, the words were marked as having double stress, similarly to such English words as maintain.

Using this material, we evaluated the possible effects of dialect variation, of word structure, and of the pragmatics of the utterances upon the assignment of stress. Neither the segmental structure of the words nor the factor of morphology produced an effect on the location of stress in the target words. It was obvious that the recurrence of the answers could be viewed as a possible factor that contributed to the alternation of stress. This means that stress assignment may be conditioned by changes in 
the attitudinal or emotional implications conveyed by the speakers in the repeatedly produced utterances (for more details, see Aasmäe \& Ross 2005). A systemic study of stress assignment in the context of the pragmatics of an utterance, as well as of stress alternation due to the rhythmic tendencies of Erzyan speech, is a task for further research.

This experiment also allowed us to identify the informants' dialect background as an essential factor underlying the tendencies of stress assignment in the material. It was possible to distinguish four speaker groups among the 33 informants whose results on the assignment of stress differed, as shown in Figure 1. Stress alternation was the most frequent in the responses of speaker group 1; the occurrences of stress on the word-initial syllable were somewhat higher than on a subsequent syllable in the responses of group 2. In groups 3 and 4, stress was predominantly on the word-initial syllable; in the responses of speaker group 4, the occurrences of stress on the wordinitial syllable were the most frequent. The share of double (or unidentified) stress was nearly the same (13-14\%) for all groups.

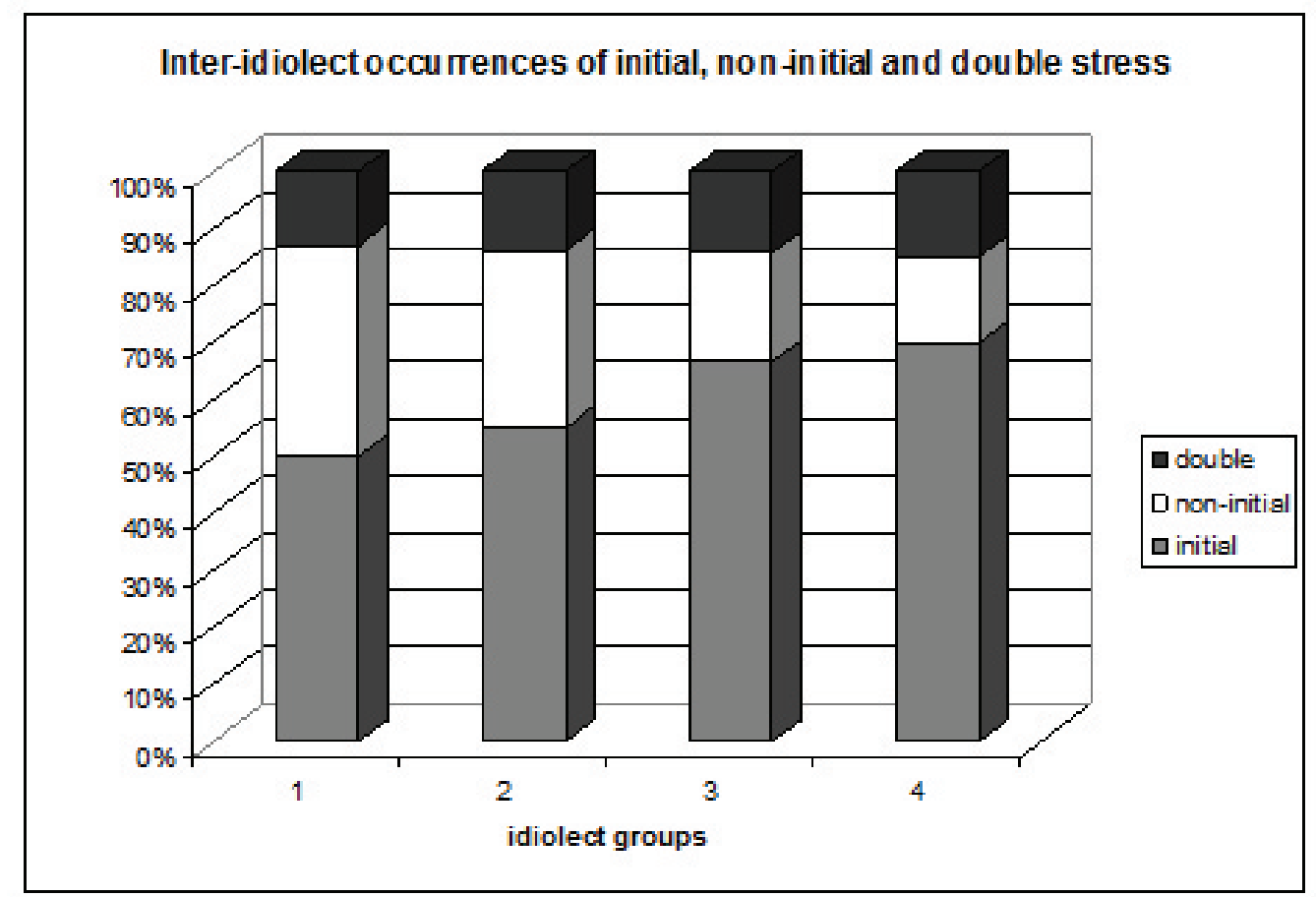

Figure I. Number of speakers/tokens - group I: 13/367, group 2: 9/25I, group 3: 6/149, group 4: $5 / 130$.

The informants in speaker groups 1 to 4 were from the following Erzyan localities $(M R=$ Republic of Mordovia):

- Group 1: Ardatov, Čukaly, Lunga (Ardatov, MR); Alovo, Andrejevka, Mordovskie Dubrovki, Nizovka (Atjaševo, MR); Paradejevo (Ičalki, MR); Čornaja Rečka (Isakly, Samara), Ivancevo (Lukojanov, Nižnij-Novgorod), Mordovskoje Afońkino (Čeremšan, Tatarstan). 
- Group 2: Djurki, Kel'vjadni, Kučenjajevo, Mordovskie Syresi, Sabančejevo, Tarasovo, (Atjaševo, MR); Varmazejka (Boĺšoje Ignatovo, MR).

- Group 3: Berezniki, Guzyncy, Staryje Naimany, Šugurovo (Boĺšie Berezniki, MR); Papulevo (Ičalki, MR); Standrovo (Teńguševo, MR).

- Group 4: Dubjonki (MR); Kočkurovo, Sabajevo (Kočkurovo, MR); Drakino (Torbejevo, MR); Malyj Tolkaj (Pohvistnevo, Samara).

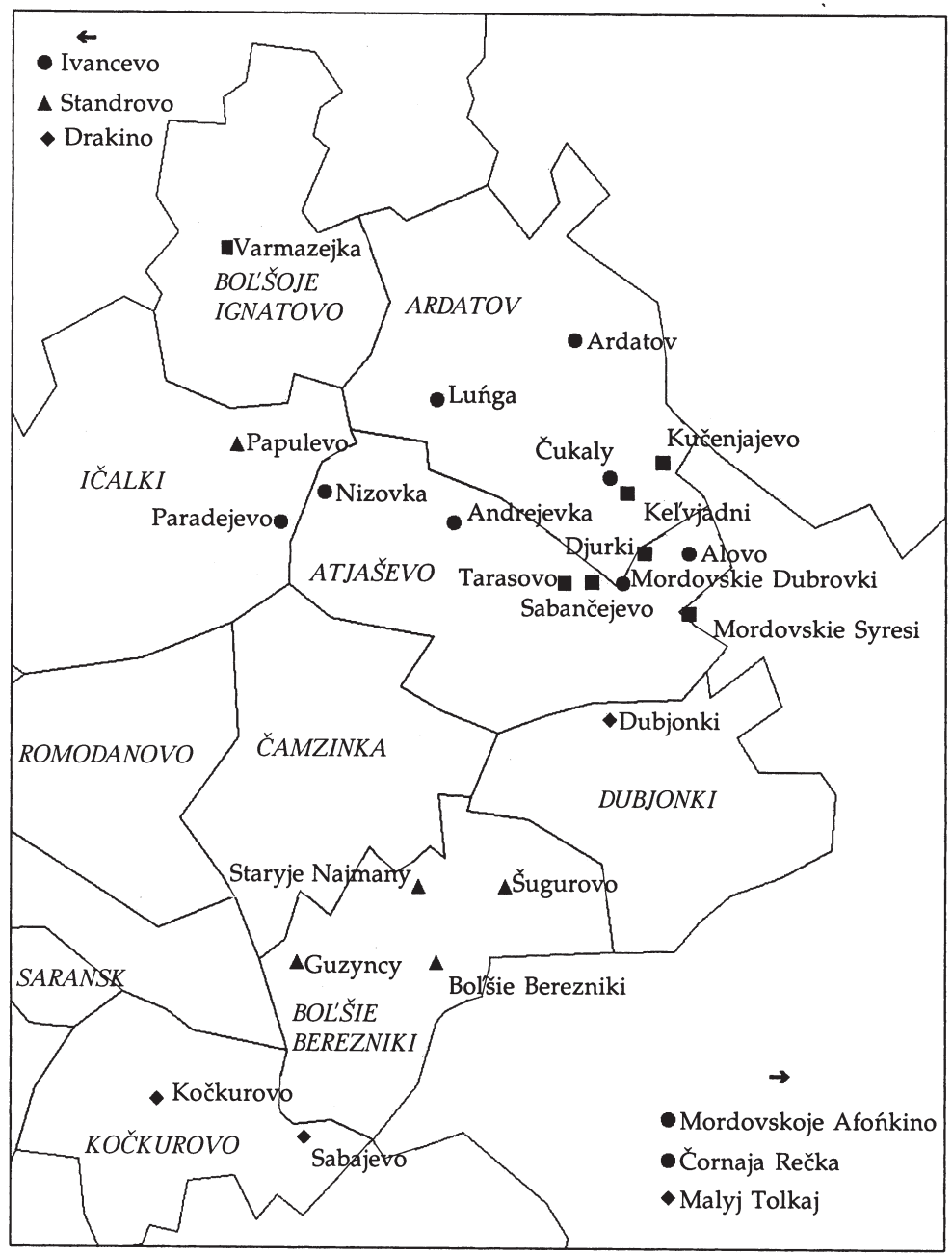

Map 2. Geographical distribution of the sub-dialects (symbols: • group I, a group 2, group 3, group 4; map: Peeter Päll).

For the identification of the speaker groups, we also took an account of the vowel quality in the unstressed syllables. The informants of group 1 produced fully formed vowels in unstressed syllables (kudoso 'at home'; vel'ese 'in the village') while in the productions of the informants from group 2 the quality of vowels in non-initial unstressed syllables displayed certain variation (cp.: kudusə, vel'ese/ä). The informants' productions in groups 3 and 4 systematically showed different patterns of vowel 
reduction - moderate vowel reduction ( $k u d u s a ̆ / \partial, ~ k u d \partial s a ̆$; välisä/a) in group 3 and radical vowel reduction $(k u d(\partial) s a ̆ / \partial, v a ̈ l '(\partial) \mathrm{s} a \check{l} / \partial)$ in group 4 . In the productions of speakers from groups 3 and 4, the vowel $\ddot{a}$ occurred.

In addition to the factor of vowel quality, the measurement data on vowel durations in the stressed and unstressed syllables supported the results on the assignment of stress. Table 1 shows the durations of stressed and unstressed vowels in di- and trisyllabic words produced by the 33 informants. For the measurements, we used the software package PRAAT (see Boersma \& Weenink; versions: 2003 to 2013). In the table, v1 and v2 stand for the duration of vowels in the stressed first and unstressed second syllables (number of observations: 475; number of informants: 33 ).

Disyllabic words

Trisyllabic words

\begin{tabular}{|l|r|r|r|r|r|r|r|}
\hline Erzya & $\mathrm{v} 1$ & $\mathrm{v} 2$ & $\mathrm{v} 1 / \mathrm{v} 2$ & $\mathrm{v} 1$ & $\mathrm{v} 2$ & $\mathrm{v} 3$ & $\mathrm{v} 1 / \mathrm{v} 2$ \\
\hline Group 1 & 108.7 & 109.3 & 1.0 & 89.8 & 86.5 & 90.9 & 1.1 \\
\hline & 15.9 & 15.6 & 0.2 & 17.1 & 13.3 & 16.9 & 0.3 \\
\hline Group 2 & $* 107.9$ & 97.4 & 1.1 & $* 97.5$ & 76.8 & 83.1 & 1.3 \\
\hline & 18.9 & 16.7 & 0.2 & 21.8 & 12.7 & 23.0 & 0.3 \\
\hline Group 3 & $* 121.9$ & 110.6 & 1.2 & $* 91.7$ & 75.6 & 88.4 & 1.3 \\
\hline & 21.08 & 27.4 & 0.3 & 22.4 & 19.1 & 25.7 & 0.3 \\
\hline Group 4 & $* 111.6$ & 94.7 & 1.2 & $* 93.7$ & 70.3 & 82.3 & 1.4 \\
\hline & 22.5 & 17.0 & 0.3 & 20.7 & 13.7 & 23.1 & 0.4 \\
\hline
\end{tabular}

Table I. Mean durations (ms) of stressed and unstressed syllable nuclei (vl, v2, v3) and duration ratios ( $\mathrm{vl} / \mathrm{v} 2)$ with standard deviations in di- and trisyllabic words (spontaneous speech). Statistically significant differences $(p<.0 \mathrm{l})$ between $\mathrm{vl}$ and $\mathrm{v} 2$ are starred $(*)$.

The results reveal a difference between the data of group 1 and of groups 2, 3, and 4. In the data of group 1, which showed a high mobility of stress, the duration of the stressed and unstressed vowels tended to be equal in both di- and trisyllabic words. The slight difference between the vowel durations in trisyllabic words was not statistically significant. Hence, in this variety of Erzya, stress and the inherent duration of vowels might be relatively independent.

In groups 3 and 4, stressed syllable vowels were longer than unstressed syllable vowels in both di- and trisyllabic words. There was a statistically significant difference between the vowel durations. In these varieties, stress, which gravitates to the word-initial syllable, affects the vowel durations. Asymmetry between the vowel durations conditions the occurrence of vowel reduction in the unstressed syllable. In the data of speaker group 4, which showed the dominance of word-initial stress and radical vowel reduction, the duration ratios were higher than in the data of the other groups. In the results for group 2, the difference between the vowel durations in disyllabic words was lower than in the data for groups 3 and 4. In trisyllabic words, the third syllable vowel tended to be as long as the vowel in the first stressed syllable in all the three groups, which implies that the third syllable might have had additional stress. Analogous measurement results were obtained by using controlled speech in Erzya (for more details, see Aasmäe 2006). 
The speaker groups thus identified are, in principle, compatible with the aforementioned groups of the Erzyan dialects, differentiated with respect to the factor of morpho-phonology, as well as geography. As far as speaker groups 1 to 4 are concerned, they include several varieties spoken in diaspora. The mixed (Shoksha) varieties (which constitute group 5 in the dialect grouping currently in use) are split between speaker groups 3 and 4. In the productions of the speaker from Standrovo (the Tengushevo region) stress appeared to be more movable than in the productions of the speaker from Drakino (the Torbeyevo region). It is relevant to mention that the dialect varieties in speaker groups 3 and 4 have undergone Mokshan influence.

\subsection{Data analysis: Moksha}

The data of Moksha derive from the analysis of controlled speech materials - target words consisting of 1 to 6 syllables produced in a frame sentence. Each word appeared in the sentence twice - in phrase- and sentence-final position. This method made it possible to test the effects of the utterance on the assignment of stress as well as on the vowel duration data.

\section{Example:}

märgalin maksă, af śijäa. 'I would say liver, not silver.' märgaliń śijä, af maksă. 'I would say silver, not liver.'

Eight speakers from the following localities (the Central dialect group) read the material:

- Mordovskaya Kozlovka of the Atyuryevo region (4 informants)

- $\quad$ Polskoye Tsybayevo of the Temnikov region (1 informant)

- Mordovskiye Parki of the Krasnoslobodsk region (1 informant)

- Zaitsevo of the Kovylkino region (2 informants)

In the analysis of data on Mokshan controlled speech (total number of tokens: 1664), inter-speaker differences were not taken into account. All the speakers were from the Central dialect group areas and the data on the productions of the speakers showed little variation. The pooled data on the assignment of stress in the test words showed a prevalence of word-initial stress (nearly $90 \%$ of the total number of the test words). Variation in the assignment of stress mainly occurred in the words with $i$ (or $u$ ) and $a$ (or $\ddot{a}$ ) in the initial and non-initial syllable, respectively: śijä 'silver', kundasamak 'you will catch me'. Alternation in the position of stress in such words occurred in the productions of different speakers, as well as of the same speaker. This is an observation made by $\mathrm{H}$. Paasonen as well.

Treatises on dialects and other literature indicate that Mokshan spontaneous speech and poetry, especially folk songs, display stress alternation (e.g. Devayev 1963: 275; Maĺkina 1990: 21). Future research should include a comparative analysis of stress assignment in spontaneous and controlled speech. At this stage, we can suggest that the mobility of stress in oral Mokshan speech is unlikely to be higher 
than in the oral productions of the Erzyan speakers of group 4. In this respect, mixed Mokshan varieties (influenced by Erzya, e.g. the sub-dialects of Gorodishche in the Penza region) might show specificity.

Vowel duration data based on the Mokshan material (see Table 2) were analogous to those that we obtained for the speakers of Erzya from group 4. Table 2 shows pooled data on the duration of vowels in di- and trisyllabic words produced by eight speakers. In the test words that occurred in phrase- and sentence-final positions, stress was located on the word-initial syllable. In the unstressed syllables, vowel reduction occurred: e.g. in ajd'amaJt' 'you chased me', the vowel $a$ occurred as a schwa in the unstressed second syllable (as well as in the third syllable, if no secondary stress occurred there).

Disyllabic / Trisyllabic words

\begin{tabular}{|l|l|l|l|l|l|l|l|}
\hline Moksha & v1 & v2 & v1/v2 & v1 & v2 & v3 & v1/v2 \\
\hline Phrase-final words & $* 116.0$ & 97,5 & 1.2 & $* 106.1$ & 74.7 & 85.9 & 1.5 \\
$\mathrm{n}=451 / 110$ & 28.7 & 24.3 & 0.4 & 22.4 & 19.6 & 25.1 & 0.5 \\
\hline Sentence-final words & 114.2 & 112.5 & 1.1 & $* 105.8$ & 80.38 & 104.6 & 1.4 \\
$\mathrm{n}=433 / 117$ & 27.6 & 25.6 & 0.3 & 25.5 & 22.8 & 24.8 & 0.4 \\
\hline
\end{tabular}

Table 2. Mean vowel durations, $m s$ ( $v l=$ first vowel, $v 2=$ second vowel, $v 3=$ third vowel), and mean durational ratios between stressed and unstressed syllable nuclei ( $v 1 / v 2)$, with standard deviations (st.d.): di- and trisyllabic words in phrase- and sentence-final position (stress located on odd-numbered syllables). Statistically significant differences $(p=0.00 \mathrm{I})$ between $\mathrm{vl}$ and $\mathrm{v} 2$ are starred $(*)$.

The duration ratio, especially in trisyllabic words, showed asymmetry between the durations of the stressed first and unstressed second syllables, as was clearly observable in the results for the Erzyan speakers of groups 3 and 4. It is obvious that the results for the Mokshan speakers show somewhat higher duration ratios than those in the results for the Erzyan speakers. As in the data of Erzya, the third-syllable vowels tended to be longer than the vowels of the unstressed second syllable. In the data of Moksha, the vowels of unstressed syllables were systematically reduced (for details, see Aasmäe et al 2013: 47-62).

The materials of both Erzya and Moksha allow us to suggest that stress functions as a category belonging to the prosody of the utterance rather than to that of the phonological word. Data based on the aforementioned sentences read by the informants of Moksha and on analogous utterances read by Erzyan informants (meŕekšniń..., avol... 'I was about to say..., not...') in an experiment conducted earlier (see Lehiste et al. 2003: 48-83) revealed a dependence of stress assignment on the syllable count in the words constituting a phrase.

In the materials of both Erzya and Moksha, the test words were preceded by a trisyllabic word (meŕekšniń/märgalinn'). In some of the utterances, the speakers produced this word as a trisyllabic foot. There were also occurrences of secondary stress on the final syllable, in addition to main stress on the first syllable of this word. The syllable that received secondary stress constituted a disyllabic foot with the initial syllable of some of the test words; stress in the test words in such cases was located on the second syllable. 
Example

Erzya: merekšniń kundasamak

Moksha: märgaliń kundasamak

The durational data presented above in Table 1 and Table 2 showed that the vowels of the third syllable in trisyllabic test words were longer than the vowels of the preceding unstressed syllable in both the Erzyan and Mokshan materials. In the analyses of stress assignment on trisyllabic and longer words, the occurrence of additional (or secondary) stress was apparent. The speakers generally tended to realize the words as a succession of disyllabic feet. Less frequently, trisyllabic feet occurred. As stress is not contrastive either in Erzya or in Moksha, the location of stress in the words alternated. It means that "...the higher-level rhythmical stress can disregard word boundaries causing movement of word stress to the second, fourth, etc. syllables..." (Lehiste et al. 2003: 86).

The succession of the feet can be demonstrated with the help of Figure 2, which captures the contours of fundamental frequency for the five-syllable Mokshan word oćulgydyma 'grow, magnify' (for details, see Aasmäe et al 2013: 66-73).

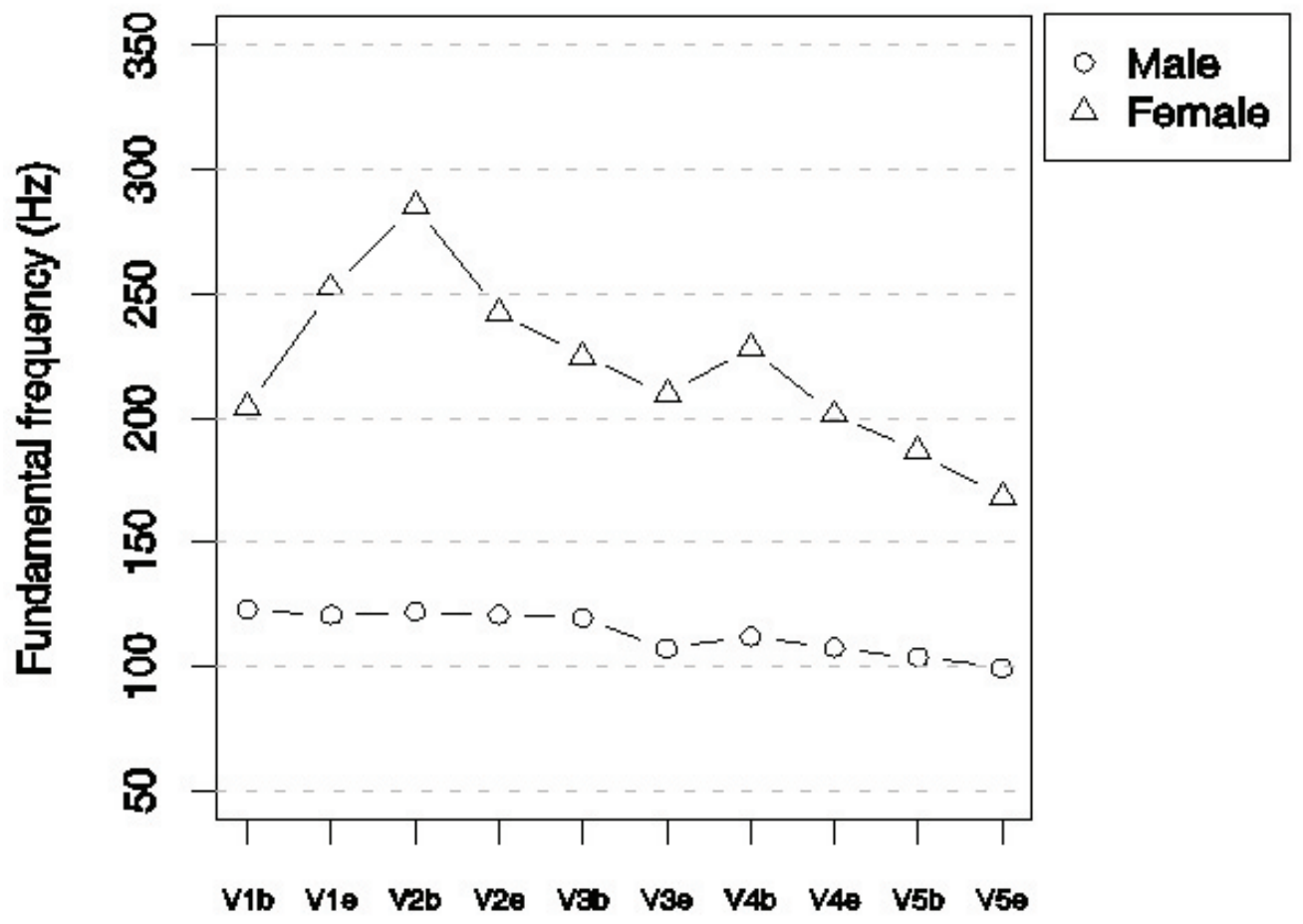

Figure 2. F0 contours on five-syllable words in phrase-final position: words with stress on the first syllable. (Aasmäe et al. 2013: 70).

Judging by the difference in fundamental frequency, we can assume that the first foot might have had primary stress and the second foot secondary stress. Variation in the placement of stresses and the realization of disyllabic and trisyllabic feet in 
polysyllabic words needs a detailed analysis. In this respect, the Erzyan varieties from speaker group 1, which showed no dependence of vowel duration in either disyllabic or trisyllabic words, deserve special attention. In order to define whether polysyllabic words constitute duration-based feet in these varieties, it would be necessary to broaden the experiment. From the point of view of the acoustic manifestations of stress in Erzya, the phenomenon of "indistinct stress" is obscure. Data for all the four speaker groups showed that it was difficult to identify a stressed syllable in 13-14\% of the test words. The question arises as to whether this feature is common to all the Erzyan dialects and it persists in the dialects influenced by Moksha as well.

On the other hand, it is the task of further research to evaluate the possibility that stress alternation in Mokshan words with the high and low vowels $(i, u-a, \ddot{a})$ is conditioned by the prosody of the utterance rather than being an inherent phonological feature of the word.

\section{The convergence of H. Paasonen's observations and the findings of current research}

To conclude the analyses, we will conjecture the positions that the types of dialects observed by Paasonen might occupy among the speaker groups identified with the help of the present-day data. H. Paasonen distinguished between the features of stress in the Erzyan dialects of Maresevo and Kazhlytka, namely he noted indistinct and highly movable stress in Maresevo versus distinct stress in Kazhlytka. According to M. E. Evsevyev (1929/1963: 315), who acknowledged H. Paasonen's contribution to the development of research in the phonetics of Mordvin, the Erzyan varieties of Maresevo and Khlystovka, on the one hand, and the Mokshan varieties of Kalyayevo, Kazhlytka and Drakino, on the other hand, are similar. Paavo Ravila (1929: 88) considered the varieties of Maresevo and Khlystovka transitional, due to the variation of the quality of vowels in non-initial syllables - the vowel $o$ tends to be substituted by $u$-and distinguished these varieties from "pure $o$-dialects" (like the variety of Atrat in Alatyŕ, the present-day Chuvash Republic). Accordingly, Maresevo and Khlystovka might occupy a position among the varieties of group 2 .

Further, H. Paasonen found similarity between the Erzyan variety of Kazhlytka and the Mokshan variety of Staroye Pshenevo, in which he noticed the dominance of word-initial stress and radical vowel reduction. According to Evsevyev (1929/1963: 314-315), the varieties of Kazhlytka and Drakino are similar to that of Kolyayevo. However, Paasonen drew no parallel between Kolyayevo and the Mokshan dialect of Staroye Pshenevo. Hence, Kazhlytka might belong to group 4, similarly to Drakino, while the variety of Kolyayevo may be among the varieties of group 3, where Standrovo is categorized.

In the Erzyan materials used by H. Paasonen, there is no evidence of dialects that would be comparable to those of speaker group 1. On this account, reference can be made to M. E. Evsevyev (1929/1963: 315) who writes that in H. Paasonen's materials, varieties of Erzya spoken in the regions of Nizhniy Novgorod, Ulyanovsk (or Simbirsk), and Penza are not represented. 
H. Paasonen's description of Mokshan stress contains no explicit notes on the divergence of features in the dialects. He has mentioned the variability of stress assignment in words as a general tendency. Apparently, there were only gradient differences noticed between stress in Staroye Pshenevo and the other varieties. In the case of Erzya, the features of stress in the varieties of Maresevo and Kazhlytka showed a marked contrast.

The sets of data considered here make it possible to admit cohesion between Paasonen's observations and the present findings on the features of Erzyan and Mokshan stress. Furthermore, the features of stress observed by H. Paasonen a hundred years ago seem to be attributable to the dialect varieties of Erzya and Moksha in their present state. We can suggest that, at least, no considerable changes may have occurred in the features of stress in the observed dialects since the end of the 19th century (or, keeping in mind that H. Paasonen's sources also include earlier published data, even since the early 19 th century). This assumption does not contradict the wellknown maxim - prosody is conservative.

\section{Conclusion}

The analyses provided here testify to the fact that there is coherence between the observations of H. Paasonen and the present-day data concerning Erzyan and Mokshan stress. They show that the dialects of Erzya are not uniform as far as the features of stress are concerned (for a different point of view, see Estill 2004: 187). The dialects of Moksha have not yet been the subject of research from this point of view.

There are two types of dialects identified in the present analysis with respect to the relationship of stress versus vowel duration (as well as quality). One is represented by Erzyan speaker groups 1 and 2, the other by the Mokshan dialects and Erzyan groups 3 and 4 (known to have undergone Mokshan influence), which gravitate toward the Mokshan type. In group 3, though, the relationship is less characteristic of that in Moksha.

Both H. Paasonen's observations and current data show dependence of the assignment of stress on the prosody of an utterance. An assumption that the assignment of stress in Erzya might be, in some way, dependent on the phrase has been made later by A. Ryabov (1932). E. Lewy (1937) has analysed, from this point of view, the accentuated materials of Erzya spoken in diaspora (the present day Saratov oblast') published by A. A. Shakhmatov (1910). Data of the Erzyan dialects presented above show that the assignment of stress might depend on the pragmatics of the utterance as well as on the characteristics of structure - namely, the syllable count in the words that constitute a phrase (and, presumably, a whole utterance) is a contributing factor. In the material of Moksha available at present, a certain amount of variation in the assignment of stress was observable; the syllable count in the words seems to be a factor that influences stress assignment, however not as much as in Erzya.

Above all, the analyses imply that in the research of stress (and prosody as a whole) in languages like Erzya and Moksha, the dialect background of the data is of crucial importance for making inferences on the data. The literary Erzya and Moksha 
languages have had little influence on the dialects, owing primarily to the insufficient native language education (and for many speakers a complete lack thereof). Hence, the overwhelming majority of native speakers communicate using their local varieties. One can make a sensational inference on comparing accentuation marked in a historical document based on one dialect type and in the productions of the same or other materials by contemporary speakers of a different dialect type. A difference found between the two sets of data may be evidence of dialect features rather than a diachronic change.

\section{References}

Aasmäe, Niina 2006: Sources of variability in the duration of stressed and unstressed syllable nuclei in Erzya: inter-idiolect data of spontaneous speech. - Linguistica Uralica XVII, 2: 81-93.

Aasmäe, Niina \& Ross, Jaan 2005: How free is alternating stress in Erzya? - Linguistica Uralica XLI, 2. 134-143.

Aasmäe, Niina; Lippus, Pärtel; Pajusalu, Karl; Salveste, Nele; Zirnask, Tatjana \& Viitso, Tiit-Rein 2013: Moksha prosody. Suomalais-Ugrilaisen Seuran toimituksia 268. Helsinki: Suomalais-Ugrilainen Seura.

Boersma, Paul \& Weenik, David 2003-2013: PRAAT, a system for doing phonetics by computer. $-<$ www.praat.org $>$.

Devayev 1963 = Деваев, С. 3. 1963: Средне-вадский диалект мокша-мордовского языка. - Очерки мордовских диалектов II. Саранск: Мордовское книжное издательство. 261-432.

Evsevyev 1963 = Евсевьев, М. Е. 1963 (written in 1929): Основы мордовской грамматики. - Избранные труды 4. Саранск: Мордовское книжное издательство.

Estill, Dennis 2004: Diachronic change in Erzya word stress. Suomalais-Ugrilaisen Seuran toimituksia 246. Helsinki: Suomalais-Ugrilainen Seura.

Feoktistow, A. P. 1990: Die Dialekte der mordwinischen Sprachen. - Martti Kahla (ed.), $H$. Paasonens mordwinisches Wörterbuch, Band I (A-J). Lexica Societatis Fenno-Ugricae XXIII, 1. Helsinki: Suomalais-Ugrilainen Seura. XXXI-CV.

Feoktistov Aleksandr \& Saarinen, Sirkka 2005: Mokšamordvan murteet. Suomalais-Ugrilaisen Seuran toimituksia 249. Helsinki: Suomalais-Ugrilainen Seura.

Korhonen, Mikko 1994: The Early History of the Kalevala Metre. - Anna-Leena Siikala \& Sinikka Vakimo (eds), Songs Beyond the Kalevala. Transformations of Oral Poetry. Helsinki. 75-87.

Lehiste, Ilse; Aasmäe, Niina; Meister, Einar; Pajusalu, Karl; Teras, Pire \& Viitso, Tiit-Rein 2003: Erzya prosody. Suomalais-Ugrilaisen Seuran toimituksia 245. Helsinki: Suomalais-Ugrilainen Seura.

Lewy, Ernst 1937: Zur betonung des ersämordwinischen im satze. - Finnisch-Ugrische Forschungen XXIV, 1-3. Helsinki. 232-245.

Maĺkina 1990 = Малькина М.И. 1990: Мордовское стихосложение. Саранск: Мордовское книжное издательство.

Paasonen, Heikki 1897: Itäsuomalaisten kansojen runoudesta. - Valvoja 17: 1-26.

Paasonen, Heikki 1893/1903: Mordvinische Lautlehre. Helsingfors.

Paasonen, Heikki 1910: Über den Versbau des mordwinischen Volksliedes. - FinnischUgrische Forschungen 10: 153-191. 
The observations of Heikki Paasonen concerning word stress in Erzya and Moksha 23

Ravila, Paavo 1929: Über eine doppelte vertretung des urfinnischwolgaischen * $a$ der nichtersten silbe im mordwinischen. - Finnisch-Ugrische Forschungen XX, 1-3. Helsinki. 83-120.

Ravila, Paavo 1973: Der Akzent im Erza-Mordwinischen. - Finnisch-Ugrische Forschungen XL, 1-3. Helsinki. 169-176.

Ryabov 1932 = Рябов, А. П. 1932: Об ударении в эрзя-мордовском языке. - Революиия и письменность. Москва.

Sarv, Heno 2002: Indigenous Europeans East of Moscow. Tartu: Tartu University Press.

Shakhmatov 1910 = Шахматов, А. А. 1910: Мордовский этнографический сборник. С.-Петербург.

Tsygankin 1979 = Цыганкин, Д. В. 1979: Фонетика эрзянских диалектов. Саранск: Мордовский государственный университет имени Н. П. Огарёва.

Yermushkin $1984=$ Ермушкин = Г. И. Ареальные исследования по восточным финноугорским языкам (эрзя-мордовский язык). Москва: ИздательствоНаука. 